\title{
Kadar Testosteron Darah Pasien Setelah Pemberian Jamu Aprodisiaka Di Rumah Riset Jamu“Hortus Medicus" Tawangmangu
}

\author{
Danang Ardiyanto, Tofan Aries Mana \\ Balai Besar Penelitian dan Pengembangan Tanaman Obat dan Obat Tradisional \\ Tawangmangu, Badan Litbangkes Kementrian Kesehatan RI \\ Jl. Raya Lawu No. 11 Tawangmangu Karanganyar Jawa Tengah \\ e-mail : $\underline{\text { drdanank@gmail.com }}$
}

\begin{abstract}
Aphrodisiac known as a substance for increasing sexual desire especially in men. Giving aphrodisiac herbs to increase libido requires adequate scientific evidence, especially in efficacy. One indicator of efficacy is to measure blood testosterone levels. The study design was quasi-experimental study, pre-post test design. A clinical trial design with pre-post test designed was performed at the "Hortus Medicus" the Center for Research and Development of Medicinal Plants and Traditional Medicine Tawangmangu to assess blood levels after administration of aphrodisiacs herbs. A total of 25 subjects volunteered to follow the trial, given the herbal formula for two months. The study was conducted at the Clinic of Jamu Scientification" Hortus Medicus" Tawangmangu from March to December 2012. The giving of Jamu consisting of temulawak rhizome 15 grams, 3 grams of cabe jawa fruit, 9 grams of pegagan herb, 3 grams of krangean fruit, and 3 grams of adas seed can increase blood testosterone levels subject. By using the T test, testosterone levels increased significantly with $p<0.05$ at day 28 and day 56 when compared to day 0. Studied jamu formula has proven to have an aphrodisiac effect
\end{abstract}

Keyword : herbs, efficacy, pre post test

\begin{abstract}
ABSTRAK
Aprodisiaka dikenal sebagai zat untuk meningkatkan gairah seksual khususnya pada lakilaki. Pemberian jamu aprodisiaka untuk meningkatkan libido memerlukan bukti ilmiah yang memadai terutama dalam efikasinya. Salah satu indikator efikasi adalah dengan mengukur kadar testosteron darah. Sebuah penelitian uji klinik dengan desain pre-post test telah dilakukan di Rumah Riset Jamu "Hortus Medicus" Balai Besar Litbang Tanaman Obat dan Obat Tradisional Tawangmangu untuk menilai kadar testoseron darah setelah pemberian jamu aprodiaka. Sebanyak 25 subjek secara sukarela mengikuti penelitian ini mendapatkan terapi formula jamu selama 2 bulan. Formula jamu merupakan infusa yang terdiri dari rimpang temulawak 15 gram, buah cabe jawa 3 gram, herba pegagan 9 gram, buah krangean 3 gram, biji adas 3 gram diminum 2 kali sehari. Kadar testosteron subyek diukur pada awal (hari ke-0), hari ke 28 dan hari ke 56. Hasil uji T antara kadar testosteron pada H-0 dibandingkan $\mathrm{H}-28$, didapatkan nilai $\mathrm{p}=0,000$, sedangkan hari ke-0 dibandingkan hari ke-56 didapapatkan nilai $\mathrm{p}=0,000$. Hal tersebut menunjukkan perbedaan yang bermakna $(\mathrm{p}<0,05)$ antara sebelum dengan sesudah perlakuan. Dapat disimpulkan formula jamu untuk aprodisiaka meningkatkan kadar testosteron darah subjek.
\end{abstract}


Kadar Testosteron Darah Pasien setelah Pemberian Jamu Aprodisiaka di Rumah Riset Jamu“Hortus Medicus" Tawangmangu

Kata Kunci: ramuan, khasiat, pre post test

\section{PENDAHULUAN}

Berbagai mitos seks yang beredar di masyarakat telah menyebabkan pria merasa sebagai makhluk seksual yang lebih hebat dari pada wanita. Pria dapat merasa sangat kecewa kalau ternyata ia gagal memberi kepuasan seksual pada wanita. Bagi pria gangguan fungsi seksual berupa gangguan dorongan seksual, gangguan ereksi, gangguan ejakulasi, dan gangguan orgasme menyebabkan depresi, stres, bahkan berakibat mengganggu hubungan suami istri yang bisa menimbulkan percekcokan dan berujung perceraian. ${ }^{1,2}$

Afrodisiaka adalah semacam zat perangsang yang konon dapat meningkatkan gairah seks. ${ }^{2}$ Afrodisiaka juga dapat diartikan sebagai makanan, obat, adegan atau perlengkapan yang dapat menimbulkan atau meningkatkan gairah seksual atau libido. Afrodisiaka dapat digambarkan sebagai beberapa zat yang dapat meningkatkan rangsangan seks dan atau kesenangan seksual. ${ }^{1,2}$

Keamanan jamu agar dapat dipakai dalam pelayanan kedokteran formal perlu didukung oleh data yang sahih. Indikator yang banyak dipakai untuk melihat keamanan adalah fungsi hati dan fungsi ginjal. Hasil penelitian ramuan formula jamu aprodisiaka yang terdiri dari infusa rimpang temulawak 15 gram, buah cabe jawa 3 gram, herba pegagan 9 gram, buah krangean 3 gram, biji adas 3 gram terbukti sebagai formula yang practically non toxic. Pemberian dosis maksimal sebesar $5000 \mathrm{mg} / \mathrm{kg} \mathrm{BB}$ $(1000 \mathrm{mg} / 200 \mathrm{~g} \mathrm{BB})$ ramuan temulawak, adas, krangean, cabe jawa dan pegagan pada empat kelompok tikus percobaan (@ kelompok terdiri dari 4 ekor tikus jantan dan 4 ekor tikus betina) selama 7 hari tidak menunjukkan adanya gejala tremor, konvulsi, muntah, diare, perubahan kondisi kulit (rontok, terkelupas), gangguan pada mata (merah, pupil mengecil), gerakan tubuh (miring, menekuk), saliva (ngeces) dan poliuria. Tidak ada satu pun tikus percobaan yang mengalami kematian. Sehingga dari hasil uji toksisitas akut dapat dikatakan bahwa ramuan cabe jawa, pegagan dan temulawak tidak bersifat toksik dengan dosis lethal semu sebesar $1000 \mathrm{mg} / 200 \mathrm{~g}$ BB. Pada uji toksisitas sub kronik, formula ini tidak mempengaruhi fungsi ginjal hewan coba. ${ }^{3,4,5,6}$

Sehubungan dengan hal diatas maka dilakukan penelitian studi klinik formula tanaman obat untuk aprodisiaka terutama pada parameter efikasi dalam meningkatkan kadar testoseron. Hasil penelitian ini diharapkan dapat menghasilkan formula yang terbukti berkhasiat sebagai aprodisiaka sehingga bisa dimanfaatkan oleh masyarakat, dan pelayanan kesehatan formal.

\section{METODE PENELITIAN}

Uji klinik dilakukan di Rumah Riset Jamu "Hortus Medicus" Balai Besar Litbang Tanaman Obat dan Obat Tradisional, Tawangmangu Jawa Tengah dari bulan Februari sampai Desember 2012. Penelitian menggunakan desain quasi eksperimental pre dan post test design. Bahan baku berupa simplisia dilakukan determinasi dan dikontrol kualitasnya dengan pemeriksaan mikrobiologi, angka jamur dan angka lempeng total di Laboratorium B2P2TO2T Tawangmangu.

Kriteria inklusi: Subyek pria yang secara subjektif mengeluh mengalami penurunan libido atau potensi seks (frekuensi coitus) yang menginginkan aprodisiakayang datang ke RRJ Hortus Medicus, sudah menikah, setuju mengikuti penelitian dengan menanda tangani informed consent. Kriteria eksklusi: Pria yang tidak dianjurkan melakukan aktifitas seksual 
dikarenakan ada riwayat penyakit jantung dan pembuluh darah coroner, subyek dengan riwayat infarksi miokardial, stroke, aritmia yang mengancam kehidupan dalam waktu 6 bulan terakhir (dengan pengakuan), subyek dengan hipotensi pada saat beristirahat (tekanan darah kurang dari 90/50), subyek dengan hipertensi sedang atau berat (tekanan darah lebih dari 170/110), pasien mengonsumsi obat yang mempengaruhi parameter penyakit yang diobservasi.

Formula yang diberikan berupa Rimpang temulawak 15 gram, buah cabe jawa 3 gram, herba pegagan 9 gram, buah krangean 3 gram, biji adas 3 gram. Mulai hari pertama subyek penelitian diberi ramuan simplisia (sediaan kering) formula aprodisiakayang telah dikemas dan disertai aturan merebus dan minum jamu ( satu kemasan pagi dan sore), pagi direbus dengan empat gelas air, hingga air yang tersisa kira kira duagelas untuk diminum $2 \mathrm{x}$ sehari satu gelas selama 2 bulan. Subjek penelitian yang telah menandatangani informed consent, pada hari sebelum intervensi (H0) dilakukan anamnesis identitas subjek, riwayat penyakit, gejala klinis, pemeriksaan fisik diagnostik, dan pengukuran fungsi ginjal (ureum dan kreatinin) sebagai data awal/pembanding. Pengukuran kadar ureum dan kraetinin darah dilakukan oleh paramedis independen.

\section{HASIL DAN PEMBAHASAN}

Pengumpulan data telah dilakukan di klinik Hortus Medicus B2P2TOOT selama bulan Maret sampai Desember 2012. Skrining dilakukan oleh dokter pada pasien rawat jalan, setelah memenuhi kriteria inklusi, subyek diberi formula jamu untuk aprodisiaka, yang diminum setiap hari (2 kali/hari) selama 2 bulan. Subyek penelitian melakukan kontrol ke dokter peneliti setiap minggu sekali untuk diperiksa fisiknya dan diberikan bahan jamu untuk dikonsumsi setiap harinya

Kemanfaatan jamu didasarkan atas adanya perbaikan parameter klinis dan laboratorium sebelum dan sesudah pemberian jamu yang diukur setiap pasien berkunjung untuk kontrol.

\section{Kadar Testosteron darah}

Pada uji klinik kadar testosteron darah diukur pada hari ke 0 , hari ke 28 dan hari ke 56, dapat dilihat di Tabel 1.

Tabel 1. Rata-rata Kadar Testosteron pada hari pengukuran

\begin{tabular}{lcccc}
\hline \multicolumn{1}{c}{ Kadar Testosteron } & N & Mean & Sd & Hasil Uji \\
\hline Hari ke 0 & 25 & 396,39 & 97,97 & \\
Hari ke 28 & 25 & 446,38 & 98,52 & $0,000^{*}$ \\
Hari ke 56 & 25 & 509,31 & 100,68 & $0,000^{*}$ \\
\hline
\end{tabular}

*uji T membandingkan setiap pengukuran dengan kadar testosteron awal (hari 0)

\section{PEMBAHASAN}

Sesuai dengan namanya,
aprodisiaka dapat diartikan sebagai peningkat gairah seksual/libido. Subyek penelitian adalah laki-laki yang sudah menikah, sehingga pengukuran peningkatan gairah seksual diukur dengan mengukur frekuensi hubungan seksual yang dilakukan sebelum dan selama pemberian jamu aprodisiaka.

Dari hasil didapatkan kenaikan frekuensi coitus dalam seminggu pada subyek sebelum dan selama pemberian jamu. Sebelum pemberian jamu rata-rata 
melakukan coitus 1,08 kali/minggu, sedangkan setelah pemberian jamu selama 28 hari, rata-rata menjadi 2,08 kali/minggu. Setelah pemberian jamu selama 56 hari, rata-rata coitus naik 2,84 kali/minggu. Setelah diuji dengan menggunakan uji $\mathrm{T}$, kenaikan tersebut bermakna secara statistik.

Kenaikan libido dapat dijelaskan secara ilmiah, karena di dalam formula jamu untuk aprodisiaka ini mengandung beberapa bahan yang mempengaruhi dorongan seksual. Cabe jawa dan krangean memiliki fungsi analeptik yang membuat tubuh terasa segar, dan memiliki senyawa-senyawa lain yang secara fisiologis dapat melancarkan peredaran darah pada sistem saraf pusat (cerebral) atau sirkulasi darah tepi (perifer). Efek meningkatkan sirkulasi darah ini terjadi juga pada genital pria. Peningkatan sirkulasi darah akan memperbaiki fungsi organ. 4 Temulawak dan pegagan memiliki fungsi adaptogen, yaitu meningkatkan daya tahan tubuh terhadap kelemahan fungsi tubuh dan penyakit serta stres. Adas berperak sebagai fungsi tonik, yaitu menciptakan tenaga, mendukung metabolisme untuk terbentuknya tenaga. ${ }^{5}$ Sinergisme dari kandungan formula jamu tersebut menghasilkan efek aprodisiaka yang meningkat. Ini sesuai dengan filosofi jamu yang memiliki sifat holistik.

Pada studi klinik ini kadar testosteron darah diukur pada hari ke 0 , hari ke 28 dan hari ke 56. Rata-rata kadar testosteron darah pada awal penelitian adalah 396,39 ng/dl. Dari 25 subyek yang diberikan jamu, semua subyek mengalami peningkatan kadar testosteron pada saat pengukuran hari ke 28 dan 56 setelah pemberian jamu. Rata-rata kadar testosteron darah pada hari ke 28 adalah 446,38 ng/dl dengan standar deviasi 98,2 ng/dl dan pada hari ke 56 rata-rata kadar testosteron adalah 509,31 ng/dl dengan standar deviasi 100,68 ng/d Dengan menggunakan uji $\mathrm{T}$, kadar testosteron naik secara bermakna dengan $\mathrm{p}<0,05$ pada saat hari ke 28 dan 56 bila dibandingkan dengan hari ke 0 .

Sebagai hormon, testosteron dan hormon steroid lain disintesis dari prekursor kolesterol. Sintesis testosteron diawali oleh terjadinya pembentukan pregnenolon dari kolesterol..$^{5}$ Konversi kolesterol menjadi pregnenolon merupakan urutan dua kali reaksi hidroksilasi yang diikuti dengan reaksi pemutusan ikatan karbon pada rantai samping. Senyawa sterol (bentuk steroid dalam tumbuhan) yang berstruktur mirip kolesterol dapat diubah menjadi pregnenolon ${ }^{6}$. Telah diketahui bahwa salah satu senyawa kimia yang terkandung dalam cabe jawa adalah $\beta$-sitosterol (termasuk senyawa sterol) ${ }^{6}$. Penambahan $\beta$-sitosterol ke dalam sistem mitokondria testis babi dapat menghasilkan pregnenolon dengan laju relatif $98 \%$ terhadap pembentukan pregnenolon dari kolesterol pada sistem sama. ${ }^{7}$ Kesamaan struktur memungkinkan dikonversinya sterol tertentu menjadi hormon steroid ${ }^{\mathbf{6}, 7}$. Senyawa saponin yang terkandung dalam buah cabe jawa merupakan senyawa dengan struktur dasar sterol (bagian aglikon) yang berikatan dengan bagian glikosida (gugus gula). Sterol dalam bentuk glikosida yaitu saponin ( $\beta$ sitosterol- $\beta$-D-glikosida) di dalam lambung yang bersifat asam mengalami pemutusan bagian gula, sehingga dapat memberikan efek seperti sterol bebas ${ }^{7}$. Dari berbagai hasil penelitian di atas diketahui bahwa ekstrak cabe jawa (Piper retrofractum Vahl.) cukup aman, mempunyai efek androgenik dan meningkatkan kadar hormon testosteron tikus percobaan serta sudah diketahui karakterisasinya baik sebagai simplisia maupun ekstrak etanol $95 \%$.

\section{KESIMPULAN}

Formula jamu yang terdiri atas rimpang temulawak 15 gram, buah cabe jawa 3 gram, herba pegagan 9 gram, buah krangean 3 gram, biji adas 3 gram terbukti 
Kadar Testosteron Darah Pasien setelah Pemberian Jamu Aprodisiaka di Rumah Riset Jamu“Hortus Medicus" Tawangmangu

efektif untuk aprodisiaka dengan meningkatkan kadar testosteron subyek.

\section{SARAN}

- Perlu diteliti lebih lanjut mekanisme formula sampai ke tingkat reseptor yang akan memberikan bukti yang kuat tentang mekanisme tersebut.

- Nilai keefektivan biaya terapi formula jamu dan perbandingan dengan obat konvensional juga perlu diteliti lebih lanjut.

\section{UCAPAN TERIMA KASIH}

Penulis mengucapkan terima kasih kepada Kepala Badan Litbangkes dan Kepala Balai Besar Penelitian dan Pengembangan Tanaman Obat dan Obat Tradisional atas dana penelitian yang diberikan. Terima kasih juga kepada PPI Balai Besar Litbang Tanaman Obat dan Obat Tradisional, dokter dan apoteker di Klinik Saintifikasi Jamu Hortus Medicus Tawangmangu.

\section{DAFTAR PUSTAKA}

1. Anwar NS. 2001. Manfaat obat tradisional sebagai afrodisiak serta dampak positifnya untuk menjaga stamina. Makalah pada Seminar Setengah Hari "Menguak Manfaat Herbal bagi Vitalitas Seksual "Jakarta,13 Oktober 2001. 8p.

2. Nuraini A. 2003. Mengenal etnobotani beberapa tanaman yang berkhasiat sebagai aprodisiaka. InfoPOM, Badan Pengawas Obat dan Makanan Republik Indonesia;IV(10):1-4.

3. Rahmawati. 2011. Uji Efek Afrodisiaka Lima Ramuan Jamu terhadap Libido Tikus Jantan, Balai Besar Litbang TOOT

4. Guyton AC, John EH. 1997. Buku Ajar Fisiologi Kedokteran. Edisi 9. Jakarta: EGC

5. Yakubu MT, Akanji MA, Oladiji AT (2007). Male sexual dysfunction and methods used in Assessing Medicinal Plants with Aphrodisiac Potentials. Pharmacognosy Review 1(1): 49-56.

6. Sa'roni, Pudjiastuti, Adjirni. 1989. Penelitian efek androgenik dan anabolik buah cabe jawa. Cermin Dunia Kedokteran;59:22-24.

7. Taryono RA. Cabe jawa. Penebar Swadaya. 2004:1-63

8. Isnawati A, Endreswari S, Pudjiastuti, Murhandini. 2002. Efek mutagen ekstrak etanol buah cabe jawa (Piper retrofractum Vahl.). Jurnal Bahan Alam Indonesia;1(2):63-67. 